\title{
Book Description
}

Local communities have adapted for centuries to challenging surroundings, resulting from unforeseen natural hazards. Vernacular architecture often reveals very intelligent responses attuned to the environment. Therefore, the question that emerged was: how did local populations prepare their dwellings to face frequent earthquakes?

It was to respond to this gap in knowledge, that the SEISMIC-V research project was instigated, and this interdisciplinary international publication was prepared. The research revealed the existence of a local seismic culture, in terms of reactive or preventive seismic resistant measures, able to survive, if properly maintained, in areas with frequent earthquakes.

The fundamental contribution and aims of the publication were to enhance:

-The disciplinary interest in vernacular architecture;

-Its contribution to risk mitigation in responding to natural hazards;

-To encourage academic and scientific research collaboration among different disciplines;

-To contribute to the improvement of vernacular dwellings, which half of the world's population still inhabits nowadays.

Fifty international researchers and experts presented case studies from Latin America, the Mediterranean, Eastern and Central Asia and the Himalayas region, with reference to 20 countries, i.e. Algeria, Bolivia, Bhutan, Chile,

China, Egypt, El Salvador, Greece, Haiti, Italy, Japan, Mexico, Morocco, Nepal, Nicaragua, Peru, Romania, Taiwan, Turkey and a closer detailed analysis of Portugal. This publication brings together 43 contributions, with new

perspectives on seismic retrofitting techniques and relevant data, addressing vernacular architecture; an amazing source of knowledge, and to this day, home to 4 billion people. 


\section{Table of Contents}

\section{Part 1: Framework}

Vernacular architecture: A paradigm of the local seismic culture

F. Ferrigni

Vernacular architecture?

G.D. Carlos, M.R. Correia, S. Rocha \& P. Frey

Seismic-resistant building practices resulting from Local Seismic Culture

J. Ortega, G. Vasconcelos \& M.R. Correia

Practices resulting from seismic performance improvement on heritage intervention

R.F. Paula \& V. Cóias

Criteria and methodology for intervention in vernacular architecture and earthen heritage

M.R. Correia

Structural conservation and vernacular construction

P.B. Lourenço, H. Varum, G. Vasconcelos \& H. Rodrigues

Seismic retrofitting of historic earthen buildings

C. Cancino \& D. Torrealva

Local building cultures valued to better contribute to housing reconstruction programs

T. Joffroy \& P. Garnier

\section{Part 2: Local seismic culture around the world}

Local seismic culture in Latin America

L.F. Guerrero Baca \& J. Vargas Neumann

Local seismic culture in the Mediterranean region

L. Dipasquale \& S. Mecca

The central and eastern Asian local seismic culture: Three approaches

F. Ferrigni

The earthquake resistant vernacular architecture in the Himalayas

Randolph Langenbach

Traditional construction in high seismic zones: A losing battle? The case of the 2015

Nepal earthquake

X. Romão, E. Paupério \& A. Menon 
Case study: Local seismic culture in vernacular architecture in Algeria

A. Abdessemed, Y. Terki \& D. Benouar

Case study: Assessment of the seismic resilience of traditional Bhutanese buildings

T. Ilharco, A.A. Costa, J.M. Guedes, B. Quelhas, V. Lopes, J.L. Vasconcelos \& G.S.C. Vasconcelos

Case study: Vernacular seismic culture in Chile

N. Jorquera \& H. Pereira

Case study: Seismic resistant typologies technology in vernacular architecture in

Sichuan Province, China

J. Yao

Case study: Seismic retrofitting in ancient Egyptian adobe architecture

S. Lamei

Case study: Seismic resistant constructive systems in El Salvador

F. Gomes, M.R. Correia \& R.D. Nuñez

Case study: Seismic retrofitting of Japanese traditional wooden structures

N. Takiyama

Case study: Seismic retrofitting constructive typology of vernacular Moroccan architecture (Fez)

A. Abdessemed-Foufa

Case study: Local seismic culture in Romanian vernacular architecture

M. Ha־rma`nescu \& E.S. Georgescu

Case study: Local seismic culture in Taiwan vernacular architecture

Y.R. Chen

Part 3: Local seismic culture in Portugal

Recognising local seismic culture in Portugal, the SEISMIC-V research

M.R. Correia \& G.D. Carlos

Seismic hazard analysis: An overview

J.F.B.D. Fonseca \& S.P. Vilanova

A brief paleoseismology literature review: Contribution for the local seismic culture study in Portugal

M.R. Correia, M. Worth \& S. Vilanova

Portuguese historical seismicity 
G.Sousa

Seismic behaviour of vernacular architecture

H.Varum, H. Rodrigues, P.B. Lourenço \& G. Vasconcelos

The design of 1758's master plan and the construction of Lisbon 'downtown': A humanistic concept?

V. Lopes dos Santos

Timber frames as an earthquake resisting system in Portugal

E.Poletti, G. Vasconcelos \& P.B. Lourenço

Part 4: Portuguese local seismic culture: Assessment by regions

Lisbon: Downtown's reconstruction after the 1755 earthquake

G.D. Carlos, M.R. Correia, G. Sousa, A. Lima, F. Gomes \& V. Lopes dos Santos

The 1909 earthquake impact in the Tagus Lezíria region

E. Gomes, A. Lima, G.D. Carlos \& M.R. Correia

Costal Alentejo region: Identification of local seismic culture

F. Gomes, A. Lima, G.D. Carlos \& M.R. Correia

Seismic-resistant elements in the Historical Centre of Évora

G.D. Carlos, M.R. Correia, G. Sousa, A. Lima \& F. Gomes

Seismic-resistant features in Lower Alentejo's vernacular architecture

A. Lima, F. Gomes, G.D. Carlos, D. Viana \& M.R. Correia

Seismic vulnerability of the Algarve coastal region

G.D. Carlos, M.R. Correia, G. Sousa, A. Lima, F. Gomes, L. Félix \& A. Feio

The high and intense seismic activity in the Azores

F. Gomes, M.R. Correia, G.D. Carlos \& A. Lima 


\section{Part 5: Typology performance study}

Seismic behaviour assessment of vernacular isolated buildings

J. Ortega, G. Vasconcelos, P.B. Lourenço, H. Rodrigues \& H. Varum

Seismic behaviour analysis and retrofitting of a row building

R.S. Barros, A. Costa, H. Varum, H. Rodrigues, P.B. Lourenço \& G. Vasconcelos

Seismic vulnerability of vernacular buildings in urban centres-the case of Vila Real de Santo António

J. Ortega, G. Vasconcelos, P.B. Lourenço, H. Rodrigues \& H. Varum

\section{Part 6: Conclusions of the research}

Systematisation of seismic mitigation planning at urban scale

D.L. Viana, A. Lima, G.D. Carlos, F. Gomes, M.R. Correia, P.B. Lourenço \& H. Varum

Systematisation of seismic retrofitting in vernacular architecture

A. Lima, M.R. Correia, F. Gomes, G.D. Carlos, D. Viana, P.B. Lourenço \& H. Varum

Common damages and recommendations for the seismic retrofitting of vernacular dwellings

M.R. Correia, H. Varum \& P.B. Lourenço 